\title{
Tissue cyst forming coccidia; Toxoplasma gondii and Neospora caninum as a cause of disease in farm animals Siv Klevar
}

\author{
Address: National Veterinary Institute, Department of Animal Health, P. O. Box, 8156 Dep, N-0033 Oslo, Norway
}

Email: Siv Klevar - siv.klevar@vetinst.no

from Perinatal Death In Domestic Animals: The 20th Symposium of the Nordic Committee for Veterinary Scientific Cooperation (NKVet) Reykjavik, Iceland. 26-27 April 2007

Published: 12 December 2007

Acta Veterinaria Scandinavica 2007, 49(SuppI I):SI doi:I0.II86/I75I-0I47-49-SI-SI

This abstract is available from: http://www.actavetscand.com/content/49/SI/SI

(c) 2007 Klevar; licensee BioMed Central Ltd.

\section{Introduction}

Toxoplasma gondii and the closely related Neospora caninum are important obligate intracellular apicomplexan parasites causing a wide range of diseases in different host species. Their life cycles are similar, consisting of a) asexual stage where multiplying tachyzoites trigger lesion development in different tissues and eventually develops to persistent tissue cysts in intermediate hosts (mainly CNS and muscular tissue) and b) sexual stages where oocysts are produced in intestinal tissues of the final hosts. The final hosts for $T$. gondii are all felids (the domestic cat is most important), and the dog is presently the only definitive host known for N. caninum. Although the two parasites are closely related they do exhibit important differences, for example, T. gondii is known to be a major cause of reproductive failure in sheep, but is not an important pathogen in abortion and congenital infection in cattle, whereas the opposite is true for N. caninum.

\section{Toxoplasma gondii}

T. gondii is one of the most successful parasites worldwide as it can infect any warm blooded nucleated cell. Toxoplasmosis in animals can either be an acute fatal infection, a subclinical infection, or most importantly, a disease of pregnancy in women, sheep, goats and pigs. There are three molecular strains of T. gondii of which Type 1 is acutely virulent and usually results in high mortality in mice. Molecular strain type 2 is less virulent, and persistently infected mice will obtain high numbers of tissue cysts. Type 2 is also the strain isolated in clinical human toxoplasmosis and in persistent infections in sheep and pigs. Tissue cysts in infected rodents and birds will frequently cause young cats to contract a primary infection and consequently, huge amounts of infective oocysts will contaminate pastures and lead to toxoplasma abortions in sheep. The natural immunomodulation that occurs during pregnancy in the sheep will prevent inflammatory immune responses that normally inhibit parasite multiplication, thereby making the ovine placenta particularly vulnerable to parasite invasion. A primary infection of pregnant sheep with $T$. gondii may result in early foetal death, abortion, or birth of a live, weak lamb depending on when infection first occurred during pregnancy. The earlier infection occurs in gestation, the more severe the consequences to the developing foetus. A characteristic finding in ovine toxoplasmosis is the white spot placenta caused by multifocal areas of necrosis $[1,2]$.

T. gondii is a major cause of abortion of sheep and goats worldwide, particular in the temperate countries where climatic conditions for oocysts survival and sporulation are optimal. In Norway, Skjerve et al. showed that $18 \%$ of slaughtered lam and 44\% of sheep herds were infected with T. gondii [3]. In 1976, Waldeland et al. estimated that $T$. gondii was the cause of nearly $80 \%$ of the lamb mortality in Norway [4]. Even today, toxoplasmosis is the most frequently diagnosed cause of abortion in sheep at the Pathology department at the National Veterinary Institute (NVI). Other agents of infectious ovine abortions diagnosed at NVI are bacterial infections such as Listeria monocytogenes and Salmonella diarizonae (Bjørn Bratberg, personal communication). In UK, other differential diag- 
noses of ovine abortions are enzootic (chlamydial) abortions, campylobacteriosis and Border disease. A diagnosis of toxoplasmosis as a cause of abortion and neonatal mortality depends on the clinical and post-mortem picture, and on laboratory investigations like serology, immunohistochemistry and PCR.

\section{Neospora caninum}

In 1984 Bjerkås et al. [5] described an apicomplexan protozoan parasite closely related to Toxoplasma gondii in a dog brain, and the parasite was described as a species in 1988 [6]. Since then, neosporosis has emerged as a serious disease leading to abortion and congenital infection in cattle and to neuromuscular disorders in dogs worldwide. While $N$. caninum primarily causes disease in pregnant cattle, infections in healthy, non-pregnant animals are usually sub-clinical. Parasite identification and antibody response has been described in a range of species including humans, often without disease.

Cattle can acquire N. caninum infection either by ingestion of oocysts that are shed in the faeces of acutely infected dogs, or by vertical transmittion. Similar to ovine toxoplasmosis, the stage of gestation is an important factor in determining disease outcome in bovine neosporosis. The ingested oocysts become tachyzoites in the blood. In a process termed exogenous transplacental infection (TPI), this latter stage may immediately infect the foetus via the placenta. However, a pre-existing chronic infection of the dam may become activated during pregnancy and tachyzoites may infect the foetus. This process is referred to as endogenous TPI. In contrast to ovine toxoplasmosis where abortions mainly occur after primary infection, transplacental parasite transmission is very efficient in infected cattle and will occur during consecutive pregnancies. The majority of the congenitally infected calves are born live and will be persistently infected $[7,8]$.

Recently, a supranational comparison of $N$. caninum herd seroprevalences was completed in Europe, which showed national seroprevalences to vary between $16-76 \%$ for dairy cattle and $41-61 \%$ for beef cattle. In England and Wales, the national seroprevalence was $6 \%$ and the proportion of abortion attributable to N. caninum was $12.5 \%$. Herd prevalence in Sweden is estimated to be $8 \%$ for dairy herds [9]. Results from an ongoing national seroprevalence study in dairy herds in Norway indicate a considerably lower prevalence of $N$. caninum positive herds than in Sweden.

In Norway, abortion and congenital infection in cattle is of little significance; however, from dairy and beef herds having reproductive failure/abortion storms, detection of $N$. caninum specific antibodies appears to be frequently diagnosed. Further studies are needed in order to estimate the proportion of abortion in cattle caused by N. caninum. A diagnosis of neosporosis as a cause of abortion and neonatal mortality depends on the clinical and post-mortem picture, and in addition detection of both $N$. caninum specific antibodies and direct detection of $N$. caninum either by immunohistochemisty, PCR, or isolation of the parasite in cell culture from the aborted foetus.

\section{References}

I. Innes EA, Bartley PM, Maley SW, Wright SE, Buxton D: Comparative host-parasite relationships in ovine toxoplasmosis and bovine neosporosis and strategies for vaccination. Vaccine 2007.

2. Saeij JP, Boyle JP, Boothroyd JC: Differences among the three major strains of Toxoplasma gondii and their specific interactions with the infected host. Trends Parasitol 2005, 21:476-48I.

3. Skjerve E, Waldeland H, Nesbakken T, Kapperud G: Risk factors for the presence of antibodies to Toxoplasma gondii in Norwegian slaughter lambs. Prev Vet Med 1998, 35:219-227.

4. Waldeland $\mathrm{H}$ : Toxoplasmosis in sheep. The prevalence of toxoplasma antibodies in lambs and mature sheep from different parts of Norway. Acta Vet Scand 1976, 17:432-440.

5. Bjerkas I, Mohn SF, Presthus J: Unidentified cyst-forming sporozoon causing encephalomyelitis and myositis in dogs. Z Parasitenkd 1984, 70:27I-274.

6. Dubey JP, Carpenter JL, Speer CA, Topper MJ, Uggla A: Newly recognized fatal protozoan disease of dogs. J Am Vet Med Assoc 1988, 192:1269-1285.

7. Buxton D, McAllister MM, Dubey JP: The comparative pathogenesis of neosporosis. Trends Parasitol 2002, 18:546-552.

8. Trees AJ, Williams DJ: Endogenous and exogenous transplacental infection in Neospora caninum and Toxoplasma gondii. Trends Parasitol 2005, 21 :558-561.

9. Bartels CJ, Arnaiz-Seco JI, Ruiz-Santa-Quitera A, Bjorkman C, Frossling J, von Blumroder D, Conraths FJ, Schares G, van Maanen C, Wouda W, Ortega-Mora LM: Supranational comparison of Neospora caninum seroprevalences in cattle in Germany, The Netherlands, Spain and Sweden. Vet Parasitol 2006, 137:17-27.

\begin{tabular}{|} 
Publish with Bio Med Central and every \\
scientist can read your work free of charge \\
"BioMed Central will be the most significant development for \\
disseminating the results of biomedical research in our lifetime. " \\
Sir Paul Nurse, Cancer Research UK \\
Your research papers will be: \\
• available free of charge to the entire biomedical community \\
• peer reviewed and published immediately upon acceptance \\
• cited in PubMed and archived on PubMed Central \\
• yours - you keep the copyright \\
Submit your manuscript here: \\
http://www.biomedcentral.com/info/publishing_adv.asp
\end{tabular}

